\title{
Efficacy of three different methods for side port incision wound sealing
}

\section{Eficácia de três diferentes métodos de selagem para incisão auxiliar}

Fabiana K. Kashiwabuchi', M.D.; Yasin A. Khan ${ }^{1}$, M.D.; Murilo W. Rodrigues Jr'1, M.D., Jiangxia Wang, M.S. ${ }^{2}$, Peter J. McDonnell', M.D.; Yassine J. Daoud', M.D.

\begin{abstract}
Purpose: To evaluate wound leakage and bacteria-sized particle influx in differently corneal sealed side port incisions. Methods: Four $1.5 \mathrm{~mm}$ tunnel squared incisions were created in each of four cadaveric human eyes. In each cornea, one incision was left unsealed, whereas the other three incisions were sealed using a 10-0 nylon suture, cyanoacrylate glue, or stromal hydration, respectively. A Seidel and an India ink test were performed on each eye. During each Seidel test, flourescein was applied, the IOP increased from 15 to $80 \mathrm{mmHg}$, and the IOP at which each incision started to leak recorded. During each India ink test, ink was placed on the eye and rinsed out with balanced salt solution (BSS). Ink penetration was then measured by planimetry at physiologic conditions and after an IOP plunge from $80 \mathrm{mmHg}$ to OmmHg. Results: Regardless of IOP variations, no leakage or ink inflow was observed through the glued incisions. In contrast, leakage did occur in the other three sealing methods, albeit at significantly different IOP levels in each one $(p=0.013)$. Ink inflow occurred in these sealing methods at physiologic IOP and, to a significantly greater extent, after the IOP challenge $(p<0.05)$. At both of these IOP conditions, the differences in ink influx among these three incision-sealing methods were deemed statistically insignificant. Conclusion: This study showed that glue was more effective at preventing wound leakage and bacteria-sized particle influx than other commonly used methods especially hydrosealing.
\end{abstract}

Keywords: Endophthalmitis; Cataract extraction; Limbus corneae; Intraocular pressure; Biomechanics

\section{RESUMO}

Objetivo: Avaliar o sinal de Seidel positivo e a penetração de tinta da Índia em incisões corneanas acessórias seladas por diferentes métodos. Métodos: Quatro incisões de 1,5 x 1,5mm foram criadas em cada um dos quatro olhos provindos do banco de olhos. Em cada córnea, uma incisão foi mantida sem manipulação, enquanto que as outras três incisões foram seladas respectivamente com Nylon 10-0, cola de cianoacrilato e hidratação estromal. Foram realizados dois testes: Sinal de Seidel positivo e penetração da tinta da Índia. No primeiro, foi aplicado fluoresceína gotas e a pressão intraocular (PIO) elevada de 15 para $80 \mathrm{mmHg}$. No segundo, a tinta da Índia foi aplicada sobre o olho estudado em duas situações: sob PIO fisiológica e sob variação súbita da pressão, de 80 para 0mmHg. Resultados: Na incisão selada com cola, apesar da variação da PIO, não houve vazamento e nem penetração de partículas de tinta. Por outro lado, o sinal de Seidel foi positivo nas outras três incisões em diferentes níveis de PIO ( $\mathrm{p}=0,013$ ). A penetração da tinta da Índia ocorreu nestas três incisões sob pressão fisiológica e com maior extensão após a variação da PIO (p<0,05). Esta diferença, no entanto não foi considerada estatisticamente significante quando comparadas as incisões entre si. Conclusão: No presente estudo, a cola foi mais eficaz em prevenir Seidel e entrada de partículas do que outro método comumente usado especialmente, hidratação estromal.

Descritores: Endoftalmite; Extração de catarata; Limbo da córnea; Pressão intraocular; Biomecânica

\footnotetext{
'The Wilmer Eye Institute, The Johns Hopkins University School of Medicine, Baltimore, Maryland, USA;

${ }^{2}$ Biostatistics Center, department of Biostatistics, Johns Hopkins Bloomberg School of Public Health, Baltimore, Maryland, USA.
}

Study carried out at Wilmer Eye Institute, The Johns Hopkins University School of Medicine, Baltimore, Maryland, USA.

The authors declare no conflicts of interest

Recebido para publicação em 17/1/2013 - Aceito para publicação em 19/9/2013 


\section{INTRODUCTION}

$\mathbf{C}$ ataract is the most common treatable cause of reduced visual acuity and blindness. About 1.7 million cataract surgeries are performed annually on Medicare beneficiaries $^{1}$. Furthermore, as the U.S. population ages, estimates indicate that by 2020 , the number of people with visually significant cataracts will grow to approximately 30 million (2).

Hypotony and elevated intraocular pressure (IOP) may follow uncomplicated cataract surgery. Hypotony was reported in patients evaluated in the immediate postoperative period after phacoemulsification ${ }^{(3,4)}$. On the other hand, Coleman and Trockel showed that, in the cannulated eye of a conscious human subject, voluntary blinking resulted in pressure spikes of $10 \mathrm{mmHg}$ whereas squeezing of the lids resulted in IOP as high as $80 \mathrm{mmHg}^{5}$.

Integrity of the surgical wound is a crucial factor in the prevention of postoperative infection. The purpose of this study was to evaluate the integrity of three different methods of port incision wound sealing in the cadaveric human eye model subjected to IOP fluctuation.

\section{Methods}

\section{Experimental Setting}

Four non-operated cadaveric human eyes were acquired from Tissue Banks International, Baltimore, Maryland, USA. All eyes were stored at $4^{\circ} \mathrm{C}$ in a moist chamber. Each eye was placed over a styrofoam receptacle and pins were used to fix the remaining conjunctiva in four quadrants. A 25-gauge needle (BD Biosciences, Franklin Lakes, NJ) was connected to a balanced saline solution (BSS) bag (Alcon laboratories, Fort Worth, TX) and inserted through the limbus at the 3 o'clock position, relative to the surgeon view, and parallel to the iris plane. A second 25-gauge needle was attached to a digital manometer (Sper Scientific Ltd., China) and inserted into the anterior chamber 180 degrees from the first needle. The BSS bag height was manually adjusted to maintain the IOP between 15 to $18 \mathrm{mmHg}$ before the port incisions were made. Under microscopic imaging (OPMI VISU 200, Carl Zeiss Surgical, Inc., Germany), four side port incisions were performed in each eye. Incisions with a length of $1.5 \mathrm{~mm}$ were created with $15^{\circ}$ knives (Feather Sterile Lightweight Micro Scalpels $15^{\circ}$, GF Healthy products, Inc., Atlanta, GA). A caliper was used to mark the tunnel length. All incisions were created approximately $1 \mathrm{~mm}$ away from the limbus and placed in different quadrants. One of the incisions was left unsealed, whereas the other incisions were sealed with a 10-0 nylon suture (Sharpoint, Surgical Specialties Corporation, Reading, PA), cyanoacrylate glue (Crazy glue, Elmer's products, Inc., Columbus, $\mathrm{OH})$ or by hydration with BSS, respectively.

\section{Standardized Seidel Test (outflow)}

After the wounds were sealed, a drop of fluorescein (Angiofluor ${ }^{\mathrm{TM}}$ Lite 10\%, Alliance Pharmaceuticals, Inc., Richmond, TX) was applied over the corneal surface. IOP was raised from the preset $15-18 \mathrm{mmHg}$ to $80 \mathrm{mmHg}$ by increasing the infusion bottle's height. The pressure at which each incision started to leak was recorded.

\section{India ink test (inflow)}

IOP was reset to $20 \mathrm{mmHg}$ and drops of waterproof India ink (Parker Quink, Parker Pen Co., Janesville, WI) was applied to the corneal surface and spread over all incisions. The corneal
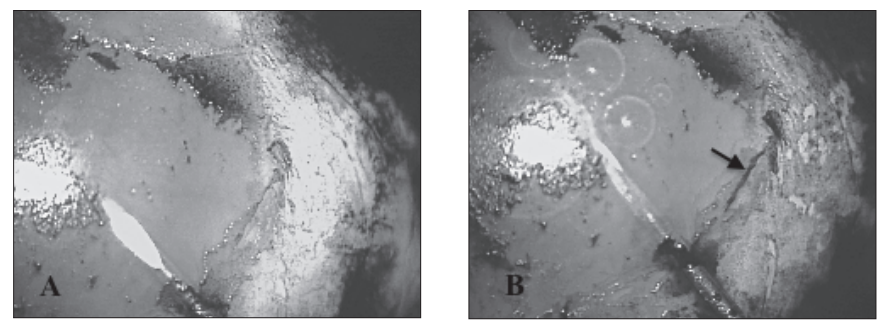

Figure 1: Cadaveric human eye surface view. India ink inflow through sutureless side port incision before (A) and after (B) intraocular pressure; note the ingress of india ink into the incision (arrow)

surface was rinsed with BSS and cleaned using a Weck-Cel sponge to maximize incision visualization. Photographic documentation was obtained using a digital imagining system attached to the surgical microscope (Medilive 3 CCD Advance Digital Camera, Carl Zeiss Surgical, Inc., Germany). Drops of India ink was then reapplied to the cornea and the IOP increased to $80 \mathrm{mmHg}$ and then abruptly decreased to $0 \mathrm{mmHg}$ by decreasing the BSS bottle's height. The ink was rinsed out once again and a second digital image was recorded (figure 1). The extent of India ink influx into the incisions was measured by planimetry using digital imaging software (AxioVision, Carl Zeiss, Inc., Germany).

\section{Statistical Analysis}

Multiple linear regression models with generalized estimating equations (GEE) and robust estimator of variances were used to compare the changes in the length of India ink ingress among the different incision types. The models used seven indicator variables for the incision types stratified into pre-IOP and post-IOP variation groups, and accounted for the correlation among the measures taken from the same eye. The log-rank test was used to compare the IOP levels at which the different types of incisions leaked. Nominally, two-sided p-values were used and were considered statistically significant if $\mathrm{p}<0.05$. Data analysis was performed using STATA version 11.0 (Stata Statistical Software; College Station, TX 2010).

\section{ResUlts}

\section{Seidel Test - Outflow}

None of the wounds showed leakage at physiologic pressures. As the IOP was increased from physiologic pressure to $80 \mathrm{mmHg}$, leakage was first observed in the hydrosealed wound, followed by the sutureless wound, and lastly the sutured wound. None of the four incisions sealed with glue showed any observable leakage, regardless of the IOP. Thus, the data from the glued wounds was omitted in the statistical analysis. The log rank test showed that the IOP at which leaking occurred was significantly different among the three remaining sealing methods $(\mathrm{p}=0.013$, table 1$)$.

\section{India ink Test}

\section{Inflow test at physiologic IOP}

At physiologic IOP, the glued incision completely prevented India ink inflow. In contrast, inflow was observed in the other three incisions. India ink particles travelled the farthest in the sutured incisions $(0.218 \mathrm{~mm} \pm 0.129)$, followed by the sutureless $(0.178 \mathrm{~mm} \pm 0.053)$, and finally by the hydrosealed incisions $(0.13 \mathrm{~mm} \pm 0.019)$. However, the difference among these three groups was not statistically significant. 
Table 1

\section{Intraocular pressure (IOP) at which leaking was observed in three differents methods of side port incision sealing in a cadaveric human model}

\begin{tabular}{ccc}
\hline Seal type & $\begin{array}{c}\text { IOP at which leaking was observed } \\
(\mathbf{m m H g})\end{array}$ & p-value \\
\hline Glue & $\mathrm{NL}, \mathrm{NL}, \mathrm{NL}, \mathrm{NL}$ & \\
Sutureless & $60,80,72, \mathrm{NL}\left(^{*}\right)$ & 0.013 \\
Hydroseal & $78,75,72,60$ & \\
Suture & $76,80, \mathrm{NL}, \mathrm{NL}$ & \\
\hline
\end{tabular}

(*)NL: No leak; P: value was calculated from the log-rank test comparing the sutureless, hydroseal and the suture methods

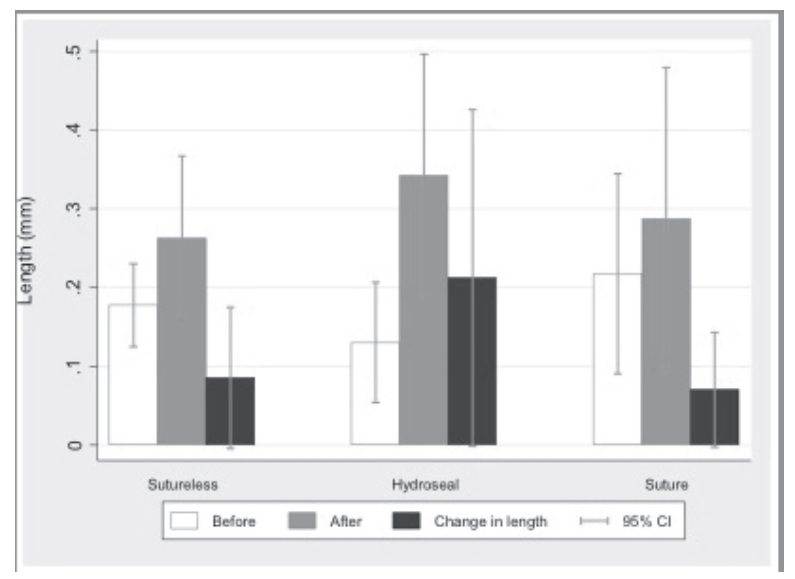

Figure 2: Changes in length of India ind inflow into the side port incision in three different wound sealing methods (sutureless, hydroseal and suture) before and after intraocular pressure challenge, in cadaveric human eye. Significance based on multiple linear regression models with generalized estimating equations (GEE) and robust estimator of variances

\section{Inflow test after IOP challenge}

Subsequent to the IOP variation, the glue-sealed incisions remained completely resistant to India ink inflow and no particles were observed in the incision sites. On the other hand, India ink influx was observed among the other three incision-sealing methods and was significantly greater when compared to the same methods at physiologic IOP (figure 2). Among these, the highest ink penetration post-IOP challenge was observed in the hydrosealed $(0.342 \mathrm{~mm} \pm 0.157)$ sutured $(0.287 \mathrm{~mm} \pm 0.196)$ and sutureless incisions $(0.262 \mathrm{~mm} \pm 0.107)$, respectively. However, this change in length of ink penetration was not statistically significant.

\section{Discussion}

Surgical wound integrity is an important factor in the prevention of postoperative infection.

A survey performed by Leaming in 2003, depicted the practice styles and preferences of ophthalmologists in the United States with regard to cataract incisions. Clear corneal incisions (CCIs) were adopted by $72 \%$ of respondents ${ }^{(6)}$. Preference for sutureless wounds varied in accordance to surgical volume. $84 \%$ of physicians who perform 1 to 5 surgeries per month and $95 \%$ of physicians who do more than 51 cataract surgeries per month opted for sutureless wounds. Our study replicated postoperative IOP variations and suggests that these lead to a significant increase in the linear distance of bacteria-sized particle influx in sutureles incisions.

Side port incisions can be used alone, however they are typically used as auxiliary incisions to aid intraocular manipulation during surgery ${ }^{(7)}$. In addition, it has been shown that multiple instrument insertions and excessive manipulation may distort the incisions, thereby increasing the likelihood of inflow and/ or leakage during the postoperative period ${ }^{(8)}$. Chee et al. demonstrated a high incidence of side port incisions leakage after phacoemulsification ${ }^{(9,10)}$. Such leakage may lead to bacterial contamination and thus potentially to infection. Our study shows that unsealed, sutured, glued, and hydrosealed incisions that have not undergone manipulation may tolerate physiologic IOP conditions without obvious leakage.

When leakage from a corneal incision is observed, the surgeon may elect to seal the wound. Common incision sealing methods include suturing, hydrosealing, and gluing ${ }^{(8,11)}$. Each of these methods has their respective advantages and disadvantages.

Reported complications related to sutured wounds include: tissue distortion with subsequent astigmatism, focal abscesses, epithelial erosions, corneal ulcers, wound dehiscence, and giant papillary conjunctivitis ${ }^{(8,12,13)}$. In a survey of members of the American Society of Cataract and Refractive Surgery (ASCRS), Leaming showed that sutures were used in less than $15 \%$ of cases by $62 \%$ of physicians and in more than 26 of cases by $9 \%$ of participants ${ }^{(6)}$. Interestingly, an experimental study performed by May et al. suggested that suturing a corneal incision might paradoxically increase the linear distance of influx by bacteriasized particles ${ }^{(14)}$. Our study, in congruence with May et al., resulted in an observed increase in the length of ink influx in sutured incisions in comparison to those left unsutured.

In our study, hydrosealing has been shown to seal cataract incisions more effectively than the sutured and sutureless methods. However, literature suggests that the stromal edema caused by hydrosealing lasts as little as 15 minutes in operated eyes and thus is considered a transient solution ${ }^{(15,17)}$. Chee et al. performed intraoperative stromal hydration in an attempt to seal leaking incisions. However, they observed that if the incision was overly manipulated, leakage persisted regardless of the hydrosealing ${ }^{(9)}$.

Moreover, the hydrosealed wound is more susceptible to local Descemet membrane detachment than without hydration ${ }^{18}$. One explanation for this vulnerability is due to non-intentional stripping of Descemet membrane during wound hydration. Calladine et al. suggested a correlation between the amount of stromal edema and misalignment of the corneal incision ${ }^{(19)}$. Furthermore, stromal hydration after an intraocular procedure has been reported to hide an incompetent valve ${ }^{(20)}$.

The use of glue to seal corneal incisions is currently an active area in ophthalmologic research. A variety of sealants have been reported in the literature. Fibrin sealants are made of plasma derivatives and reproduce the end of the coagulation cascade. However, there is a concern regarding the risk of viral transmission due to their composition and preparation ${ }^{(8,21)}$. Adhesives such as Biodendrimer ${ }^{(22)}$, N-Butyl-2-Cyanoacrylate ${ }^{(23)}$, and 2-Octyl-Cyanoacrylate (24) have been shown to be effective in wound sealing. However, it is suggested that these adhesive substances may cause adverse effects including increased inflammation, neovascularization, and foreign body sensation ${ }^{(25,26)}$.

In our ex vivo study the glue-sealed incisions were successful in preventing both the outflow and inflow of ink particles be- 
fore and after the IOP challenge. These results strengthen the study by Degorcija et al. that demonstrated the potential application of ocular adhesives in ophthalmologic procedures ${ }^{(27)}$. Our study also showed that after the IOP challenge the hydrosealed, sutured, and sutureless incisions showed a significant increase in the length of India ink penetration when compared with values observed at physiologic IOP. In addition, this study suggests that a lack of leakage during the intraoperative period may not guarantee that the incision is resistant to the influx of bacteria-sized particles.

The current study has some inherent weaknesses that may affect its applicability to clinical practice. Firstly, the statistical power of our results is limited by the small sample size. Secondly, results obtained using cadaveric eyes cannot be directly applied to a live model. One reason is the fact that it is difficult to avoid corneal edema due to the lack of functioning endothelial cells. Thus, it is possible that our results do not accurately portray the efficacy of the studied sealing methods, especially for hydrosealing of the wound. Thirdly, there is no guarantee that the leaking patterns observed with varying IOP conditions in cadaveric eyes will resemble those of live eyes. Lastly, the corneal incisions studied in this experiment were not subjected to the repeated entry of surgical instrumentation and wound manipulation that tends to occur during cataract surgery. Future studies that take these considerations into account are necessary to verify the behavior of these different methods of corneal sealing.

\section{ConCLuSION}

Our study suggests that corneal hydration and other currently utilized sealing-methods may not be as effective as previously thought. According to our results, glue seems to confer the greatest resistance to leakage and bacteria-size particle influx.

Grant in the acknowledgement: This work supported in part by an unrestricted apart from Research to Prevent Blindness (New York, NY) Inc. to The Wilmer Eye Institute and by a nonrestricted gift from Mr. Paul Peck

Data analyses support provided by grant \#EY01765.

\section{RefERenCES}

1. West ES, Behrens A, McDonnell PJ,Tielsch JM, Schein OD. The incidence of endophthalmitis after cataract surgery among the U.S. Medicare population increased between 1994 and 2001. Ophthalmology. 2005;112(8):1388-94.

2. Congdon N, Vingerling JR, Klein BE, West S, Friedman DS, Kempen J, O'Colmain B, Wu SY, Taylor HR; Eye Diseases Prevalence Research Group. Prevalence of cataract and pseudophakia/aphakia among adults in the United States. Arch Ophthalmol. 2004;122(4):487-94.

3. Shingleton BJ, Wadhwani RA, O'Donoghue MW, Baylus S, Hoey H. Evaluation of intraocular pressure in the immediate period after phacoemulsification. J Cataract Refract Surg. 2001;27(4):524-7.

4. Valbron BF, Silva RS, Jardim D, Canedo AL, Palis M, Ambrósio Junior R. [Assessment of intraocular pressure through the ocular response analyzer before and after phacoemulsification surgery]. Rev Bras Oftalmol. 2011;70(1):11-5. Portuguese.

5. Coleman DJ, Trokel S. Direct-recorded intraocular pressure variations in a human subject. Arch Ophthalmol. 1969;82(5):637-40.

6. Leaming DV. Practice styles and preferences of ASCRS members2003 survey. J Cataract Refract Surg. 2004;30(4):892-900.

7. Stratas BA. Clear corneal paracentesis: a case of chronic wound leakage in a patient having bimanual phacoemulsification. J Cataract Refract Surg. 2005;31(5):1075.
8. Nichamin LD, Chang DF, Johnson SH, Mamalis N, Masket S, Packard RB, Rosenthal KJ; American Society of Cataract and Refractive Surgery Cataract Clinical Committee. ASCRS White Paper: What is the association between clear corneal cataract incisions and postoperative endophthalmitis? J Cataract Refract Surg. 2006;32(9):1556-9. Review.

9. Chee SP. Clear corneal incision leakage after phacoemulsification-detection using povidone iodine 5\%. Int Ophthalmol. 2005;26(4-5):175-9.

10. Chee SP,Ti SE, Lim L, Chan AS, Jap A. Anterior segment optical coherence tomography evaluation of the integrity of clear corneal incisions: a comparison between 2.2-mm and 2.65-mm main incisions. Am J Ophthalmol. 2010;149(5):768-76.e1.

11. Wallin T, Parker J, Jin Y, Kefalopoulos G, Olson RJ. Cohort study of 27 cases of endophthalmitis at a single institution. J Cataract Refract Surg. 2005;31(4):735-41.

12. Leahey AB, Avery RL, Gottsch JD, Mallette RA, Stark WJ. Suture abscesses after penetrating keratoplasty. Cornea. 1993;12(6):489-92.

13. Feizi S,Zare M. Current approaches for management of postpenetrating keratoplasty astigmatism. J Ophthalmol. 2011;2011:708736.

14. May WN, Castro-Combs J, Kashiwabuchi RT, Hertzog H, Tattiyakul W, Kahn YA, et al. Bacterial-sized particle inflow through sutured clear corneal incisions in a laboratory human model. J Cataract Refract Surg.2011;37(6):1140-6.

15. Fukuda S, Kawana K, Yasuno Y, Oshika T. Wound architecture of clear corneal incision with or without stromal hydration observed with 3dimensional optical coherence tomography. Am J Ophthalmol. 2011;151(3):413-9.e1.

16. Olson RJ. Reducing the risk of postoperative endophthalmitis. Surv Ophthalmol.2004;49 Suppl 2:S55-61. Review.

17. Vasavada AR, Praveen MR, Pandita D, Gajjar DU, Vasavada VA, Vasavada VA, et al. Effect of stromal hydration of clear corneal incisions: quantifying ingress of trypan blue into the anterior chamber after phacoemulsification. J Cataract Refract Surg. 2007;33(4):623-7.

18. Calladine D, Tanner V. Optical coherence tomography of the effects of stromal hydration on clear corneal incision architecture. J Cataract Refract Surg. 2009;35(8):1367-71.

19. Calladine D, Packard R. Clear corneal incision architecture in the immediate postoperative period evaluated using optical coherence tomography. J Cataract Refract Surg. 2007;33(8):1429-35.

20. Tam DY, Vagefi MR, Naseri A. The clear corneal tongue: a mechanism for wound incompetence after phacoemulsification. Am J Ophthalmol. 2007;143(3):526-8.

21. MacGillivray TE. Fibrin sealants and glues. J Card Surg. 2003;18(6):480-5. Review.

22. Johnson CS, Wathier M, Grinstaff M, Kim T. In vitro sealing of clear corneal cataract incisions with a novel biodendrimer adhesive. Arch Ophthalmol. 2009;127(4):430-4

23. Banitt M, Malta JB, Soong HK, Musch DC, Mian SI. Wound integrity of clear corneal incisions closed with fibrin and N-butyl-2-cyanoacrylate adhesives. Curr Eye Res. 2009;34(8):706-10.

24. Ritterband DC, Meskin SW, Shapiro DE, Kusmierczyk J, Seedor JA, Koplin RS. Laboratory model of tissue adhesive (2-octyl cyanoacrylate) in sealing clear corneal cataract wounds. Am J Ophthalmol. 2005;140(6):1039-43.

25. Sharma A, Kaur R, Kumar S, Gupta P,Pandav S, Patnaik B, et al. Fibrin glue versus N-butyl-2-cyanoacrylate in corneal perforations. Ophthalmology. 2003;110(2):291-8.

26. Kim T, Kharod BV.Tissue adhesives in corneal cataract incisions. Curr Opin Ophthalmol. 2007;18(1):39-43. Review.

27. Degoricija L, Johnson CS, Wathier M, Kim T, Grinstaff MW. Photo crosslinkable Biodendrimers as ophthalmic adhesives for central lacerations and penetrating keratoplasties. Invest Ophthalmol Vis Sci. 2007;48(5):2037-42.

\section{Author correspondence:}

Fabiana Kimie Kashiwabuchi, MD

R. Independência, nº 3358

Zip Code 15010-110 - São José do Rio Preto (SP), Brazil

Phone: +55 (17) 981760100 - Fax: +55 (17) 3214-4452

Email: fabikimie@yahoo.com.br 